\title{
Religious Habitus of Neopentecostalists and Community Life
}

\section{Habitus religioso de neopentecostalistas y vida comunitaria}

\section{Nadezhda Nikolaevna Aleksandrova}

Senior Lecturer at the Department of Religious Studies of the Institute of Social and Philosophical

Sciences and M.K,

ORCID: 0000-0002-5411-4383

Received 09-08-20 Revised 10-10-20

* Correspondence

Email: NNAleksandrova@kpfu.ru
Accepted 12-11-21 On line 03-04-21

\section{Citation:}

Nadezhda Nikolaevna Aleksandrova. (2021). Religious Habitus of Neopentecostalists and Community Life. Propósitos y Representaciones, 9(SPE2), e1086. http://dx.doi.org/10.20511/pyr2021.v9nSPE2.1086 


\begin{abstract}
This article is devoted to one of the most active Christian movements - neo-Pentecostalism. To describe the functioning of neo-Pentecostal communities in Russia, the article uses the concept of "habitus" by P. Bourdieu, thanks to which it is possible to show the role of ministry practice in the everyday communal life and the religious everyday life of a believer. The concept of "religious habitus" in the article is understood as a system of stable dispositions, functioning as a structuring principle, generating and organizing practices and beliefs, thereby setting the daily routine of a religious community. The article also examines the neo-Pentecostal teaching about the "pentahedral" ministry, about the "gifts of the Holy Spirit" and the activities of the church, and the structural principles of a religious community functioning. It is shown that a believer, within the framework of socialization in the community, goes through the following stages: calling to service, professionalization, independent service, mentoring in service. Based on field research and presented narratives, it was revealed that the choice of religious service occurs according to the following types: on the recommendation of community leaders, arbitrary disclosure of the "Holy Spirit" gifts, by personal choice, and according to the rehabilitation type. The article raises the following question: can we talk about religious service as a religious practice or as a value-rational type of religious action?
\end{abstract}

Keywords: Religious Practice, Religious Habit, Neo-Pentecostals, Religious Community, Church, Religious Everyday Life.

\title{
Resumen
}

Este artículo está dedicado a uno de los movimientos cristianos más activos: el neopentecostalismo. Para describir el funcionamiento de las comunidades neopentecostales en Rusia, el artículo utiliza el concepto de "habitus" de P. Bourdieu, gracias al cual es posible mostrar el papel de la práctica del ministerio en la vida comunitaria cotidiana y la vida cotidiana religiosa de Un creyente. El concepto de "habitus religioso" en el artículo se entiende como un sistema de disposiciones estables, que funciona como un principio estructurador, genera y organiza prácticas y creencias, configurando así la rutina diaria de una comunidad religiosa. El artículo también examina la enseñanza neopentecostal sobre el ministerio "pentaédrico", sobre los "dones del Espíritu Santo" y las actividades de la iglesia, y los principios estructurales del funcionamiento de una comunidad religiosa. Se demuestra que un creyente, en el marco de la socialización en la comunidad, pasa por las siguientes etapas: llamado al servicio, profesionalización, servicio independiente, mentoría en el servicio. Sobre la base de la investigación de campo y las narrativas presentadas, se reveló que la elección del servicio religioso ocurre de acuerdo con los siguientes tipos: por recomendación de los líderes comunitarios, divulgación arbitraria de los dones del "Espíritu Santo", por elección personal y de acuerdo con la rehabilitación. tipo. El artículo plantea la siguiente pregunta: ¿podemos hablar del servicio religioso como una práctica religiosa o como un tipo de acción religiosa de valor racional?

Palabras clave: práctica religiosa, hábito religioso, neopentecostales, comunidad religiosa, iglesia, vida cotidiana religiosa.

\section{Introduction}

Neo-Pentecostalism is one of the most active and adaptive Christian movements in the world. Originating as a charismatic revival in Pentecostal churches during the second half of the 20th century, neo-Pentecostalism was the culmination of "modern" religiosity. On the one hand, it supports the traditional communal way of life of Christian churches, which ensures the cohesion and functionality of communities, on the other hand, it constructs a new type of religiosity as "spiritual self-realization". Neo-Pentecostals strive to develop a "personal relationship with God," to find and fulfill their calling in ministry at the church. Neo-Pentecostals believe that a person can experience "being born again" and "be baptized in the Holy Spirit" through the work of the Holy Spirit. The "born-again" have a special spiritual personality (sacred self), which must improve in 
relationship with God. The neo-Pentecostal habit is developed on this principle, which determines the daily life of communities (Kormina, 2013).

The functioning of any religious community is conditioned by the social structure that streamlines the social space. P. Bourdieu believes that the principle of division, which is embedded in any symbolic system, including religion, makes social interaction predictable (Bourdieu, 2001). The religious community structures the perception and understanding of the world, and sets the system of religious practices. In other words, it forms a religious habitus - stable systems of dispositions, a structure that generates and organizes religious practices. The formation of a religious habit occurs naturally through the realization of the community religious needs. P. Bourdieu considers habitus to be the result of the history that generates it, together with the schemes for practical problem solution of social reality. Each of the historical realities of neoPentecostal community existence forms the issues of their time. The issues concerning life in the church are the supporting dispositions of habitus, structuring the community life.

\section{Materials and Methods}

The theoretical and methodological basis of our research is the concept of habitus by P. Bourdieu.

The concept of habitus is, in fact, an attempt to overcome the subjectivity of the social action interpretation and the determinism of "social structure". Habit is generated by history and itself, giving rise to individual and collective practices, it creates history. The ability to make history is conditioned by the ability of habitus to provide a "guarantee of practice constancy over time" for a social group or a class. P. Bourdieu writes that habit is a system of stable dispositions, but we mean by this formulation a system of mental schemes that allow us to structure perception, formulate thoughts, express feelings in a certain way, and practice. The stability of habitus dispositions is provided by the conditions for its formation or transmission, which occurs through the assimilation of social experience during the process of socialization in a family and society. The dispositions of habitus acquire the status of virtues, and certain patterns of behavior are recognized as approved, others as condemned.

The structure of the habit is dynamic; the production of practices is not a blind reproduction of an action pattern. The sense of "practical" collides with the historical and social conditions of the situation in which it is realized. There is also a unified law of concordance, which makes it possible to make behavior or speech recognizable, approved and recognized, legitimate in a social and historical situation. Coordination occurs due to collective practices, and adjustment is possible thanks to individuals endowed with a special status of agents-mobilizers, such as a prophet, a leader, a ringleader, and a thought leader. The consistency of habit dispositions allows individuals to form a sense of collectivity and to organize themselves into the groups based on the principle of a common habit recognition (Bourdieu, 2001).

Applying the concept of habitus to religious studies, it remains to consider a very important aspect. Religious habit by constructing the social structure of the community develops the religious subjectivity of the parishioners. "Religious subjectivity" is understood here as an aspect of the self that is realized in action and manifests itself in our predisposition, orientation, moods, expectations, attachments, stable emotional reactions, etc. It functions as a core of identity, reflecting and continuously reproducing a narrative conceptualization of "personal vocation to ministry," making the qualities and actions needed by the church (religious community) as personal virtues.

In our study, we proceed from empirical data collected during participatory observation of neo-Pentecostal communities in Kazan during 2015-2017, which includes in-depth interviews, the diaries of included observations, and the field notes by the author. 


\section{Research Results}

The life of a religious community is diverse and requires a complex social organization, but social differentiation must be legitimate, and therefore must be explained by the Divine. "Any movement in the church, any ministry cannot be done only by human efforts, moreover, this has some kind of negative connotation in the Christian world. The purpose of the church is the unity in serving God. No person possesses all the gifts, and the Church of Christ needs all the gifts to cover the needs of the church" (Pogasy \& Aleksandrova, 2019).

A religious community is the product of everyday practices constructed by religious habit. Religious habit does not act in a mechanical-deterministic manner, i.e. determining the proper or unacceptable behavior in the community through imperatives (moral or theological). The practical stimuli that determine the daily life of a religious community do not exist as an objective reality, but act only when they meet with believers who are able to recognize them. Theological teaching only sets the structural relief of practical stimulus "recognizability". P. Bourdieu clarifies that the construction of social reality, and, consequently, the formation of habitus dispositions occurs due to the generation of social group needs (class, religious community, party) into virtue (Bourdieu, 2001). So, based on the Scriptures, neo-Pentecostals single out the fivefold teaching about the gifts of ministry. Apostle, pastor, evangelist, teacher, prophet - these gifts should fully serve the church - "cover the needs of the church."

The process of being included in a religious group and choosing a religious career can be conditionally divided into several stages.

- Calling to ministry.

- Professionalization.

- Self-service ministry.

- Mentoring in the ministry.

How does a person choose to serve in the church?

Based on the data collected during participatory observation, we can conclude that the most common strategy for choosing a religious profession is the personal choice of a member of a particular ministry in the church, which is negotiated with a mentor or a leader of a home group and receives approval directly from the leader of the chosen ministry. When "born in heaven" a person receives the gifts of the Holy Spirit. "Born twice" does not know what gifts he is endowed with, he must pray for the gift to be revealed, or, as they often say in the communities, "to be released." The second option for choosing a religious profession is the decision of the community leaders. Close interaction in the community allows leaders to know their flock well enough. By noticing a person's ability or personality, ministry leaders can recommend him for a particular ministry. We associate this variant of vocation to a religious profession with collective solidarity. Ministry leaders, looking closely at the community, chose those people who were most sociable, and, therefore, the community recognized the gift of a minister. As a rule, the services for which the parishioners were selected were associated with the community as a whole: the helpers at Sunday meetings, the organizers responsible for technical and economic issue solution. The processes of collective solidarity in "recognizing a gift" can sometimes carry the elements of this gift sacralization in the community. We observed a similar case in one of the Kazan communities, when a new young minister-musician was invited to the musical ministry. At the very first Sunday meeting, the entire community noticed a change in the composition of the worship group. Most of the community knew this young man, he had a religious education and played during youth meetings. His selection into the music ministry changed his status in the community and contributed to his collective recognition of the "ministry gift".

The third option for choosing a religious profession can be considered as a situation when the gift is revealed at will. For example, prophecy, healing, divine understanding. When people with such gifts appear in the community, as a rule, "professional ministers" begin to work with them. 
The fourth option for choosing a religious profession is the rehabilitation option, when rehabilitants who have successfully completed all stages of the program and were adapted in the community become the mentors of new rehabilitants themselves. As a rule, those people who have already successfully completed the program go to such specific services as drug rehabilitation, and prison ministry.

The stage of professionalization begins when the believer has already chosen the ministry. This is a period of adaptation already in a group of ministers of a certain mission in the church, it is not limited by the time frame, someone can stay in this position for a long time. Most of the numerous ministers look closely at a person, determining what his talents are and where he can show himself. Professionalization is often a learning process in the ministry of the Spirit missions. Prophetic schools, youth prayer services, and congregations are established where senior ministers communicate with young people. The processes of professionalization in ministry are followed by independent ministry - this is usually the longest stage of ministry, which is the main and final one for most parishioners.

Not everyone grows up to mentoring in ministry, but this is a natural stage of development in charismatic communities and one of the important conditions for the Christian church management. "The Holy Spirit leads the Church of Jesus through the people filled with the Holy Spirit. Church members who are subordinate to elders may soon become such leaders. An infant is the subordinate to the caregivers until the date appointed by the Father. Then he will have to go to the private, and then to complete obedience to Christ" (Pogasy \& Aleksandrova, 2019). As we can see from the above passage of the sermon, the disclosure of the Holy Spirit gifts is important not only for the minister, but also for the general process of "building up the Church of Christ," and for this process to be godly, the institute of mentoring is developed in the churches of the neoPentecostals. The main task of the mentor is to serve the maturation and development of the mentored. The mentor should help the person to show the gifts and inspire him to serve.

Each church chooses its own growth practices in ministry. Someone leaves with their associates for a long fast, during which they discover "the truths from God," and they grow. Someone collects leadership trips or meetings with reflections in groups to open the path of growth, someone organizes leadership conferences and seminars.

\section{Conclusion}

The life of the neo-Pentecostal community is structured. The structure of the community reflects both the religious and organizational needs of the community, which, within the framework of theology, acquire an absolute character and are interpreted as "The Gifts of the Holy Spirit." At the same time, each of the roles of the neo-Pentecostal church ministers (apostle, pastor, evangelist, teacher, prophet) does not have a clear functional content, parishioners endow each other with each of the roles intuitively. The dispositions of religious habit structure the perception, irrelevant facts are excluded even before any conscious consideration as inconceivable and not subject to order, therefore, election to service is viewed not as an earthly matter, but as a divine calling.

The daily routine of a religious community, created by religious habitus, gives rise not only to the order of functioning, but also to the principles of identification within the community. Joint religious activity forms practical incentives for the expression of religious feelings (the form of prayer, the nature of worship, etc.), which are recognized by the community as acceptable or unacceptable. Believers do not identify one another at common religious events reflexively, "recognition" is intuitive. Believers feel a kinship in the Spirit (in God) and cannot always explain what this means. The non-reflective nature of this knowledge becomes the basis for the reliability of the "sacred personality action."

The ministry in the churches of the neo-Pentecostals represents a value-rational character, i.e. it is the activity in which a certain mode of action is absolutized. The practice of ministries allows you to streamline the community life, also the life of the believer himself, highlighting the 
realm of the present, something greater than the person himself, allowing an individual to leave everyday life for a while and fill his ordinary existence with meaning.

The presented consideration of ministry practices allows us to say that the practices of the Holy Spirit GIFTS preserve the stability of a community or a church social structure. It is not a person who determines the positions and statuses of ministers in the church, but the charisma that God gives him. Thus, the contradiction in the structure of a community or a church social organization is removed.

\section{Summary}

The development of service practices is multifaceted and versatile, it is primarily related to the problems of our time and goes back to the following principle: "If you see a need and can cover it, this is your calling from above to serve." Serving in neo-Pentecostal communities is not a job or a duty, but serves solely for "spiritual growth", for the realization of a "calling." Service practices allow to regulate the relations within the community, as well as to regulate the relations with society. The new Pentecostals are transforming social reality through social ministries, "sanctifying" it and realizing their religious values in society.

Social ministries are focused on the community problems and needs. In this interpretation, social services are more of a religious act than a religious practice. On the other hand, they can be considered a religious practice, since any ordered action tends to be typified, and in the religious life of a community it cannot be said that all participants of social missions reflect on their motives by participating in ministries. Orientations, the directions of ministry, as a rule, are always determined by ministry leaders, these rights are endowed by God in the form of ministry gifts, which the community has recognized for him. Participation in social services for most neoPentecostals is an integral part of their religious daily life, which takes place in time and regularly, according to the orderliness of the religious community.

\section{Acknowledgements}

The work is performed according to the Russian Government Program of Competitive Growth of Kazan Federal University.

\section{References}

Bourdieu, P. (2001). Practical meaning. SPb.: Aleteya, M.: Institute of Experimental Sociology.

Burnim, M. (1985). Culture Bearer and Tradition Bearer: An Ethnomusicologist'Rs esearcho $\mathrm{n}$ Gospel Music. Ethnomusicology, 29(3), 432-447

Hunt, S.J. (2002). Deprivation and Western Pentecostalism Revisited: The Case of "Classical" Pentecostalism/ S.J. Hunt. Pentecostudies, 1(1), 1-32.

Klyueva, V., \& Ryazanova, S. (2016). Prayer practices in the Pentecostal environment: religious communication "By vertical". Bulletin of the Orthodox St. Tikhon University for the Humanities. Series 1: Theology. Philosophy. Religious studies, 2(64), 90-102.

Kormina, Zh.V. (2013). Hygiene of the Heart: Discipline and Faith of "Reborn" Charismatic Christians. Anthropological Forum, 18, 300-320.

Kornilov, I.P., Pogasiy, A.K., Tulyanskaya, Yu.T., \& Kulchinsky, A.E. (2016). Protestants in Russia and Tatarstan: history and modernity: a collective monograph. - Yoshkar-Ola: MRIPP, - $280 \mathrm{p}$.

Kupari, H. (2016). Lifelong Religion as Habitus Religious Practice among Displaced Karelian Orthodox Women in Finland. Brill Academic Pub, 208 p.

Kuropatkina, O. V. (2012). The "New" Pentecostals and the Russian "National Idea." // Religion, State and Society. Taylor \& Francis, 40(1), 133-144

Kuropatkina, O.V. (2012). Ethnic and religious self-identification of the "new" Pentecostals in Russia: conflict or synthesis?" / Protestantism: pro et contra. Anthology. Ed. by M.Yu. Smirnov. - SPb.: RHGA,. 564-573. 
Luhrmann, T.M. (2012). When God talks back : understanding the America $\mathrm{n}$ evangelical relationship with God / by T. M. Luhrmann. Published by Alfred A. Knopf New York, 434 p.

Melvin, L. (2002). Butler "Nou Kwe nan Sentespri" (We Believe in the Holy Spirit): Music, Ecstasy, and Identity in Haitian Pentecostal Worship. Black Music Research Journal, 22(1), 85-125

Miller, D. E., \& Yamamori, T. (2007). Global Pentecostalism: The new face of Christian social engagement. Univ of California Press.

Panchenko, A.A. (2013). "Sacred Theater", the intricacies of morality and rites of passage: the anthropology of global Christianity in modern Russia. Anthropological Forum, 18, 215222.

Pogasy, A. K., \& Aleksandrova, N. N. (2019). Aspects of inculturation of neopentecostalism in the conditions of a policonfessional environment. Humanities \& Social Sciences Reviews, 7(6), 305-308. 